\title{
The germination of seeds of Epiphyllum phyllanthus (L.) Haw. (Cactaceae) is controlled by phytochrome and by nonphytochrome related process
}

\author{
Edson Simão ${ }^{1}$, Adriana Tiemi Nakamura ${ }^{1}$ \& Massanori Takaki ${ }^{1,2}$ \\ ${ }^{1}$ Departamento de Botânica, Universidade Estadual Paulista - UNESP, \\ CP 199, CEP 13506-900 Rio Claro, SP, Brazil \\ ${ }^{2}$ Corresponding author: Massanori Takaki, e-mail: massa@rc.unesp.br
}

SIMÃO, E., NAKAMURA, A.T. \& TAKAKI, M. The germination of seeds of Epiphyllum phyllanthus (L.) Haw. (Cactaceae) is controlled by phytochrome and by nonphytochrome related process. Biota Neotrop. 10(1): http://www.biotaneotropica.org.br/v10n1/en/abstract?article+bn01910012010.

\begin{abstract}
The Epiphyllum phyllanthus seeds present high sensitivity to light and their germination can be promoted by dim green safe light through the very low fluence response mediated by phytochrome A. Part of seed population have phytochrome B in active form (Pfr) enough to promote germination in darkness. Seeds of Epiphyllum phyllanthus germinate in a wide temperature range from 10 to $40{ }^{\circ} \mathrm{C}$, reaching complete germination in the range of 15 to $30^{\circ} \mathrm{C}$. Above $35^{\circ} \mathrm{C}$ the germination rate increases indicating control by a non phytochrome related process. The analysis of kinetics of seed germination indicated that the phytochrome A control is less dependent on temperature than phytochrome B controlled process.

Keywords: seed germination, very low fluence response, low fluence response.
\end{abstract}

SIMÃO, E., NAKAMURA, A.T. \& TAKAKI, M. A germinação de sementes de Epiphyllum phyllanthus (L.) Haw. (Cactaceae) é controlada pelo fitocromo e por um processo não relacionado com fitocromo. Biota Neotrop. 10(1): http://www.biotaneotropica.org.br/v10n1/pt/abstract?article+bn01910012010.

Resumo: As sementes de Epiphyllum phyllanthus apresentam alta sensibilidade à luz e a sua germinação pode ser promovida pela luz verde de segurança por meio da resposta de fluência muito baixa mediada pelo fitocromo A. Parte da população de sementes tem fitocromo B na forma ativa (Fve) suficiente para promover a germinação no escuro. Sementes de Epiphyllum phyllanthus germinam em uma ampla faixa de temperatura de 10 a $40{ }^{\circ} \mathrm{C}$, atingindo germinação completa na faixa de 15 a $30^{\circ} \mathrm{C}$. Acima de $35^{\circ} \mathrm{C}$ a velocidade de germinação aumenta indicando o controle por um processo não relacionado com o fitocromo. A análise da cinética da germinação de sementes indicou que o controle pelo fitocromo A é menos dependente da temperatura do que o processo controlado pelo fitocromo B.

Palavras-chave: germinação de sementes, resposta de fluência muito baixa, resposta de fluência baixa. 


\section{Introduction}

Seed germination is a critical stage of the life-cycle in most plant species, particularly in epiphytic plants that preset strong water seasonality (Franco 2002, Mondragon \& Calvo-Irabien 2006). Thus, seed germination success may reflect upon population size, distribution and abundance (Rojas-Aréchiga et al. 1998, Flores \& Briones 2001, Ramírez-Padilla \& Valverde 2005). Indeed, the environmental conditions of the area of species occurrence are essential to determine the seeds characteristics and its germination responses. Mainly, the light associated to the temperature can promote or inhibit the germination and then influence the seed germination process (Valverde et al. 2004, Ramírez-Padilla \& Valverde 2005, Flores et al. 2006, Cotá-Sánchez \& Abreu 2007, Simão et al. 2007).

The seed germination events in natural conditions is controlled by phytochrome present in seeds (Kronenberg \& Kendrick 1986, Takaki 2001), temperature (Válio \& Scarpa 2001, Sugahara \& Takaki 2004, Simão et al. 2007), water availability, soil or substrate type and the rate of gas exchange (Bewley \& Black 1994, Fenner \& Thompson 2005). All of those factors influence the germination alone or associated among them, so each portion or population of seeds shows different responses to the environment variations.

Several species in plant communities present seed germination responses, at least partially mediated by phytochrome (Botto et al. 1996). However, among species there is a large variation in the light-sensitive seeds, mainly in the function of the morphological and physiological characteristics (Amaral-Barolli \& Takaki 2001, Rojas-Aréchiga et al. 2001) besides of the temperature effect (Válio \& Scarpa 2001, Sugahara \& Takaki 2004) which can or not change the sensitivity of seeds to light.

The seed light sensitivity can change with the temperature of incubation (Smith 1975, Takaki et al. 1981). For instance, in highly light sensitive seeds of Arabidopsis thaliana the far-red light causes only partial reversal of the red light induction and the far-red alone can promotes germination in darkness (Botto et al. 1996). Thus, for some species, at specific conditions short period of light at very low fluence such as from dim green safe light used in photomorphogenic studies, is sufficient to trigger the germination process (Baskin, J.M. \& Baskin, C.C. 1979, Amaral-Baroli \& Takaki 2001).

In Cactaceae, the responses of seeds for germination process in arid land (Ramirez-Padilla \& Valverde 2005, Flores et al. 2006) and moist tropical areas (Cota-Sánchez \& Abreu 2007, Simão et al. 2007) are different and related to the needed conditions for seedling establishment and survival.

In the present work we studied the seed germination process in Epiphyllum phyllanthus (L.) Haw., a representative epiphytic cactacean from the Brazilian Atlantic Forest, which has wide distribution and occurs in South America between Paraguay until south of Brazil (Kimnach 1964). E. phyllanthus belongs to Hylocereeae together with Pseudorhipsalis, Disocactus, Selenicereus, Hylocereus e Weberocereus, including epiphytic and rupicule plants with the most of the species occurring in Central America. Cactaceae species have Neotropical distribution and they are found mostly in arid or semiarid environments and 220 species with epiphytic life-form in the tropical and sub-tropical rain forest, mainly the subfamily Cactoideae, and tribes Hylocereeae and Rhipsalideae (Bauer \& Waechter 2006).

E. phyllanthus has non-dormant (viviparous) seeds which are responsible for colonizing near the mother plant (Tomazi \& Figueiredo 2002) and present high mortality of viviparous seedlings during the early establishment stages (Cota-Sánchez et al. 2007). Thus effort for the maintenance of the E. phyllanthus population is crucial, mainly in degraded environments. In this context, the aim of this paper was the study of the characteristics of the germination of E. phyllanthus non viviparous seeds under light and temperature effects.

\section{Material and Methods}

Epiphyllum phyllanthus indehiscent fruits were harvested in ten specimens present on Caesalpinia peltophoroides Benth. trees at UNESP Campus at Rio Claro, São Paulo, Brazil. The fruits were opened on a sieve and the seeds washed under tap water to remove mucilage covering of the seeds. After this process the seeds were put to dry at $25{ }^{\circ} \mathrm{C}$ and stored at $10{ }^{\circ} \mathrm{C}$ in a sealed glass bottle. The all experiments were carried out within a period of four months seed storage.

For germination experiments, 25 seeds were spread on two layers of water imbibed filter paper in each of four $50 \mathrm{~mm}$ diameter Petri dishes. For white light treatment, the Petri dishes were put inside colorless and transparent plastic boxes $(10 \times 10 \mathrm{~mm})$ under day-light fluorescent lamps and dark treatment inside black boxes $(10 \times 10 \mathrm{~mm})$. Isothermic incubations were carried out inside germination chambers in the range of 5 to $45^{\circ} \mathrm{C}$ with $5^{\circ} \mathrm{C}$ intervals. White light was obtained with the aid of two $20 \mathrm{~W}$ day-light fluorescent lamps with the photon fluence rate of $32.85 \mu \mathrm{mol} . \mathrm{m}^{-1} \cdot \mathrm{s}^{-1}$ at seed level. The germination experiments were carried out within a minimum period of thirty days from sowing.

Seeds with at least $1 \mathrm{~mm}$ long roots were considered as germinated. The germinated seeds were daily scored and the dark incubated seeds were scored under dim green safe light (Amaral-Baroli \& Takaki 2001) and one control treatment was maintained in completely darkness during the experimental period with counting only at the end of the experiment. Relative frequency of germination (Equation 1).

$$
\mathrm{RF}=\mathrm{n}_{\mathrm{i}} / \mathrm{Nt}
$$

where $n_{i}$ is the number of germinated seeds between times ti- ${ }_{1}$ and $\mathrm{t}_{\mathrm{i}}$ ); germination rate (Equation 2).

$$
\mathrm{GR}=1 / \mathrm{t}
$$

where $\mathrm{t}$ is the mean time, calculated as (Equation 3).

$$
\left.\mathrm{t}=\left(\sum \mathrm{n}_{\mathrm{i}} \cdot \mathrm{t}_{\mathrm{i}}\right) / \sum \mathrm{n}_{\mathrm{i}}\right)
$$

and synchronization index (Equation 4).

$$
\mathrm{U}=\sum-\mathrm{RF} \cdot \log _{2} \mathrm{RF}
$$

where RF is the relative frequency of germination) were calculated according to Labouriau \& Osborn (1984). The Arrhenius plot of germination rates were done using (Equation 5).

$$
\text { -R. } \ln G R
$$

where: $\mathrm{R}=$ gas universal constant of $1.987 \mathrm{kcal} .(\mathrm{K} . \mathrm{mol})^{-1}$, $\operatorname{lnGR}$ is the natural logarithm of germination rate. Kinetics of seed germination was determined using the variation in the enthalpy of activation of seed germination

$$
\Delta \mathrm{H \# \eta}=\{[\mathrm{R} \cdot \mathrm{T}(\theta-\mathrm{T}) \cdot(\mathrm{Tm}-\mathrm{TM})] /[(\mathrm{T}-\mathrm{Tm}) \cdot(\mathrm{TM}-\mathrm{T})]
$$

where $\mathrm{R}$ is the gas universal constant of $1.987 \mathrm{cal}$; Tm the minimum temperature, TM the maximum temperature of germination, $\theta$ the harmonic mean between Tm and TM and T the temperature $\left({ }^{\circ} \mathrm{K}\right.$ ) (Labouriau \& Osborn 1984).

The germination percentage was transformed in arcsine of $\sqrt{ } \%$ before statistical analysis. The data were submitted to factorial analysis and One Way ANOVA followed by Tukey test at $\alpha \leq 0.05$ (Sokal \& Rohlf 1981). 


\section{Results and Discussion}

The temperature and light have different effects on the seed germination of studied cactacean species (Rojas-Aréchiga \& VázquezYanes 2000, Ramírez-Padilla \& Valverde 2005, Flores et al. 2006, Simão et al. 2007) and those two factors have more effect on the germination rates than on germination percentage, as determined in Epiphyllum phyllanthus seed germination. Here, the temperature had no significant effect on final germination percentage except at
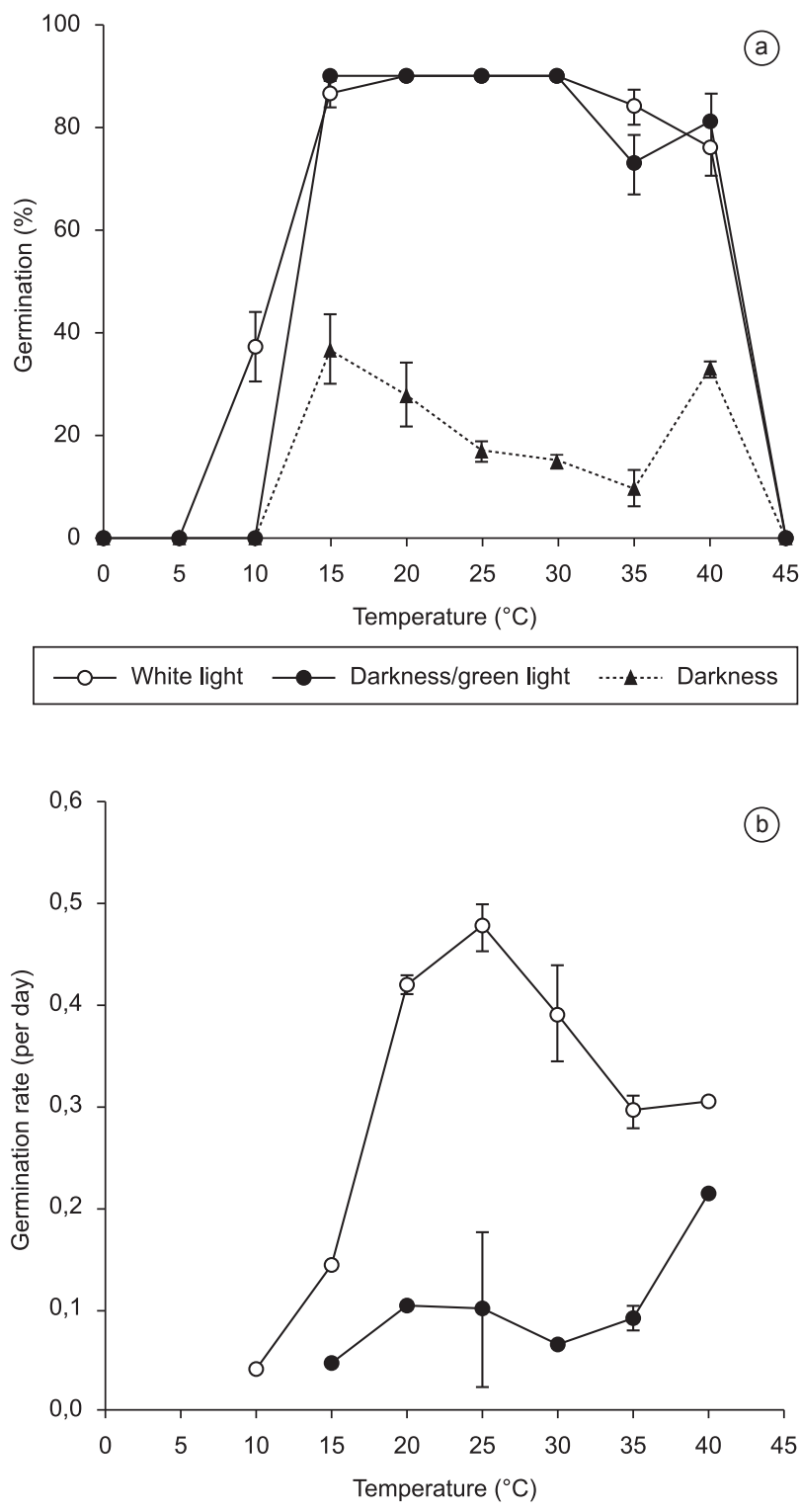

$\longrightarrow$ - White light $\longrightarrow$ Darkness/green light

Figure 1. Effects of temperature under white light (-o-), darkness with intermittent dim green safe light (darkness/green light) (-•-) and complete darkness (-- $\boldsymbol{\Delta}--)$ on Epiphyllum phyllanthus seed germination (a) and germination rate (b). The bars on the Figure represent mean \pm standard error. Germination: temperature*darknes/green safe light $(\mathrm{F}=13.95695, \mathrm{p}=0.000012)$; temperature ${ }^{*}$ white light $(\mathrm{F}=26.77646, \mathrm{p}=0.000000)$; temperature*complete darkness $(\mathrm{F}=6.672, \mathrm{p}=0.001115)$. Germination rate: temperature*darkness/ green safe light $(\mathrm{F}=130.7110, \mathrm{p}=0.000012)$; temperature* white light $(\mathrm{F}=54.13232, \mathrm{p}=0.000000)$. $45^{\circ} \mathrm{C}$ where no germination was observed and at $10{ }^{\circ} \mathrm{C}$ in darkness but the absence of white light decreased significantly $(\mathrm{p}<0.05)$ the germination rates (Figures 1a and 1b). Ramírez-Padilla \& Valverde (2005) also related the temperature effect more significant on the germination rate rather than final germination percentage in Neobuxbaumia macrocephala (F.A.C. Weber ex K. Schum.) E.Y. Dawson, N. tetetzo (J.M. Coult.) Backeb. and N. mezcalaensis Bravo (Cactaceae). At complete darkness the final percentage germination was lower than under green safe light daily counting. Those results indicate that the phytochrome $\mathrm{A}$ is controlling the germination process (Botto et al. 1996).

The minimum temperature for E. phyllanthus seeds to germinate was between 5 to $10{ }^{\circ} \mathrm{C}$ and the maximum between 40 to $45^{\circ} \mathrm{C}$. An interesting fact was a high germination percentage $(>80 \%)$ observed under temperature of $40{ }^{\circ} \mathrm{C}$ although no germination was observed at $45{ }^{\circ} \mathrm{C}$ (Figure 1). The germination synchronization indexes were lowest (or highest germination synchronization) in the range of 20 to $30{ }^{\circ} \mathrm{C}$ (Table 1 ).

Some Cactaceae species are capable to germinate in a wide temperature range between 10 to $40{ }^{\circ} \mathrm{C}$, generally reaching their highest percentages between 20 to $30^{\circ} \mathrm{C}$ (Rojas-Aréchiga \& Vázquez-Yanes 2000), and in general, seeds germinated at high rate when exposed to high temperatures when compared to seeds exposed to relatively lower temperatures (Ramírez-Padilla \& Valverde 2005, Simão et al. 2007).

The optimal temperature range for E. phyllanthus seed germination was between 20 and $30^{\circ} \mathrm{C}$ (highest germination percentage and rate and highest synchronization) corroborating Rójas-Aréchiga \& Vázquez-Yanes (2000) that reported this temperature range for seed germination of Cactaceae species. Although with high final percentage germination at $15,35,40{ }^{\circ} \mathrm{C}$ (Figure $1 \mathrm{a}, 1 \mathrm{~b}$ and 2 ) without significant difference to optimal range to temperature, wide variation in germination rate (Figure 1a, Table 1) with significant difference $(\mathrm{p}<0.05)$ among treatments were observed.

According to Labouriau \& Osborn (1984), the rate of seed germination is limited by diffusion processes at $|\Delta \mathrm{H \# \eta}|<12 \mathrm{kcal}^{\mathrm{mol}}{ }^{-1}$. The analysis of the kinetics of seed germination indicates clearly that the germination of seeds under continuous white light the diffusion process such as oxygen and water is limited by temperature in the range of 22.5 to $31.6{ }^{\circ} \mathrm{C}$ while under dark incubation with intermitent dim green safe light the range is from 18.1 to $30.7^{\circ} \mathrm{C}$. Those results indicates that in phyA controlled seed germination the temperature range is, at least $3.5^{\circ} \mathrm{C}$ broader, when the germination

Table 1. Effect of the white light and temperature on the synchronization indexes of the Epiphyllum phyllanthus seed germination.

\begin{tabular}{ccccc}
\hline Temperature $\left({ }^{\circ} \mathbf{C}\right)$ & \multicolumn{4}{c}{ Synchronization indexes } \\
\hline & Light & & Darkness/Green light \\
\hline 05 & - & - & - & - \\
10 & $2.3 \pm 0.31$ & $\mathrm{~b}^{*}$ & - & - \\
15 & $2.2 \pm 0.17$ & $\mathrm{~b}$ & $2.9 \pm 0.19$ & $\mathrm{a}$ \\
20 & $1.5 \pm 0.09$ & $\mathrm{a}$ & $2.1 \pm 0.11$ & $\mathrm{a}$ \\
25 & $1.8 \pm 0.08$ & $\mathrm{ab}$ & $2.0 \pm 0.12$ & $\mathrm{a}$ \\
30 & $1.8 \pm 0.09$ & $\mathrm{ab}$ & $2.6 \pm 0.46$ & $\mathrm{a}$ \\
35 & $2.3 \pm 0.07$ & $\mathrm{~b}$ & $2.7 \pm 0.26$ & $\mathrm{a}$ \\
40 & $2.2 \pm 0.05$ & $\mathrm{~b}$ & $2.5 \pm 0.22$ & $\mathrm{a}$ \\
45 & - & - & - & - \\
\hline
\end{tabular}

* Different letters indicate differences by Tukey test ( $\mathrm{p} \leq 0.05$.tempera-

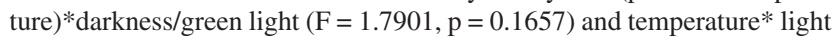
$(\mathrm{F}=4.3245 ; \mathrm{p}=0.005414)$ 


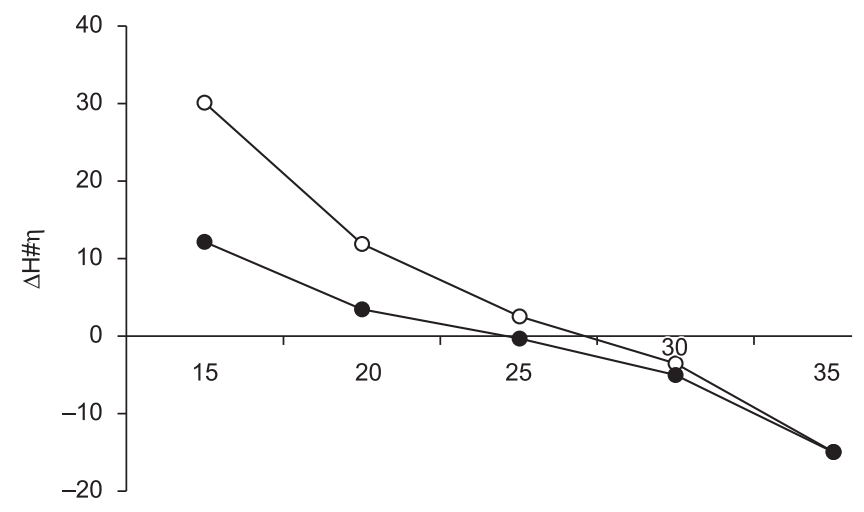

Temperature $\left({ }^{\circ} \mathrm{C}\right)$

Figure 2. Variation in enthalpy of activation $(\Delta \mathrm{H} \# \eta)$ of seed germination in seeds of Epiphyllum phyllanthus under continuous white light (-o-) and dark with daily counting under dim green safe light (-•-).

is only limited by difusion process rather than the process controlled by phyB. In another words, phyA controlled seed germination is less temperature dependent than phyB controlled seed germination at low temperatures (Figure 2).

The seeds of E. phyllanthus were light sensitive (Figure 1a, 1b and 2), and when daily scored under dim green safe light the final germination percentage was statistically similar to the treatment under continuous white light. However, the germination rate under darkness scored with green light was lower than under white light (Figure 1b) with significant difference $(\mathrm{p}<0.05)$. E. phyllanthus showed low germination percentage under complete darkness in all tested temperatures with significant $(\mathrm{p}<0.05)$ increase at high temperatures (Figure 1a). At $15^{\circ} \mathrm{C}$ seeds incubated in complete darkness presented near $40 \%$ germination and with increase in the temperature of incubation, decrease in the final percentage germination was observed until $35{ }^{\circ} \mathrm{C}$. This decrease in the germination process is due to the increase in the rate of dark reversion of Pfr. This indicates that part of the population of seeds presents pre existing Pfr of phytochrome $\mathrm{B}$ inducing the germination process.

Some articles reported the effect of light promoting seed germination in some cactacean species with different responses to light conditions suggesting the presence of phytochrome in those seeds (Nolasco et al. 1996, Rójas-Aréchiga et al. 1997, Pimienta-Barrios et al. 2004, Flores et al. 2006, Simão et al. 2007). This light sensitivity of seeds can change with the temperature of incubation (Smith 1975, Takaki et al. 1985) such as in E. phyllanthus seeds which germinate only under white light at $10{ }^{\circ} \mathrm{C}$ and increase in light sensitivity at temperature range from 15 to $40{ }^{\circ} \mathrm{C}$ (Figure 1a). In those range of temperature E. phyllanthus seeds were highly sensitive to light, because daily short periods of exposition to the dim green safe light used to score the germinated seeds were sufficient to promote germination percentage similar to continuous white light incubated seeds. The germination of seeds under green safe light was also reported by Amaral-Baroli \& Takaki (2001) in Bidens pilosa, when 5\% of phytochrome as Pfr were enough to promote complete germination. Our results with $E$. phyllanthus indicates that the seed germination is controlled by phytochrome through two distinct processes, by low fluence response by phyB and by very low fluence response by phyA (Takaki 2001) for both treatments, continuous white light and intermittent dim green safe light irradiation, respectively. The high sensitivity to light indicates that E. phyllanthus seeds such as in Hylocereus setaceus (Salm-Dyck) Ralf Bauer (Simão et al. 2007), can germinate in small gaps of the canopy or when the seeds are covered by light impermeable material, such as under the bark of trees.

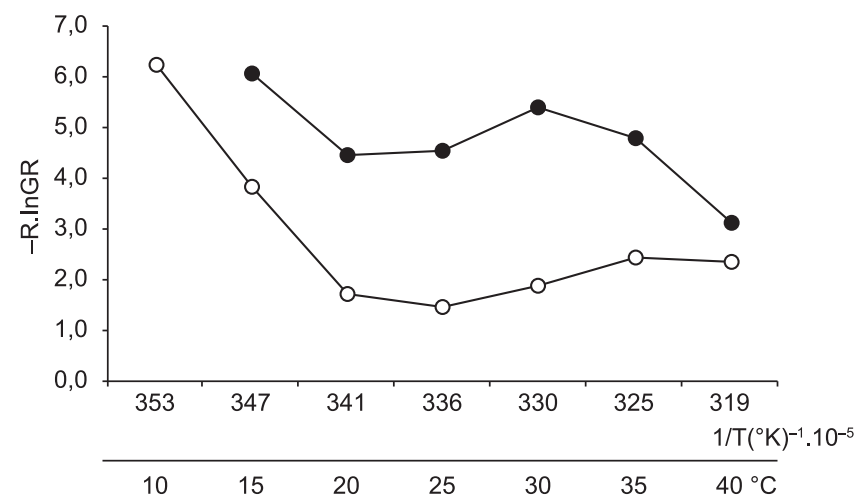

Figure 3. Arrhenius plot of germination in seeds of Epiphyllum phyllanthus under continuous white light (-O-) and dark with daily counting under dim

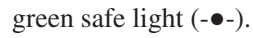

Above $35^{\circ} \mathrm{C}$ under intermittent dim green safe light irradiation the germination rate tends to increase suggesting that a non phytochrome related process controls the germination process (Figure 1b). The Arrhenius plots of germination rates of seeds treated with white light and intermittent dim green safe light irradiation indicate that in the former the lowest energy of activation of germination occurs between 20 and $30{ }^{\circ} \mathrm{C}$ and in the latter between 20 and $25^{\circ} \mathrm{C}$ and above $35^{\circ} \mathrm{C}$ (Figure 3). At 35 and $40{ }^{\circ} \mathrm{C}$ the germination process is not controlled by phytochrome, since at high temperature the rate of the dark reversion increases removing a possible pre-existing Pfr (Smith 1975). The participation of another process not related to the phytochrome control can the observed in intermitent dim green light and complete darkness incubations where low increse in the final percentage was observed. Above $35^{\circ} \mathrm{C}$ under intermitent green light the activation energy decreases confirming the non phytochrome controlled seed germination (Figure 3).

The germination of seeds of E. phyllanthus in complete darkness can be attributed to the pre existing Pfr enough to induce the germination process in part of seed population (Takaki 2001). The phytochrome controlled seed germination demonstrated here was also observed in another cactaceans such as Hylocereus setaceus (Simão et al. 2007), Pachycereus hollianus Buxb., Cephalocereus chrysacanthus (F.A.C. Weber ex Schum.) Britton \& Rose and Neobuxbaumia tetetzo (Rójas-Aréchiga et al. 1997).

The high seed viability and presence of viviparous seeds with precocious germination inside of E. phyllanthus fruits (Cota-Sánchez \& Abreu 2007), the epiphytic habit associated to high germination rate and high light sensitive seeds suggest that this species do not form seed bank under natural conditions. Although high percentage seed germination was obtained after twelve month storage at $10{ }^{\circ} \mathrm{C}$ in a sealed glass bottle indicating the orthodox seed characteristics (Simão unpublished data). For Hylocereus setaceus, another epiphytic Cactaceae, the seed bank can be formed on the bark of some tree species in places sheltered from sun light (Simão et al. 2007) demonstrating the variable responses between species of the same habitat and life-forms.

One portion of the seed populations in E. phyllanthus germinates inside de fruit before they are shed from the mother plant (Conde 1975, Cotá-Sánchez \& Abreu 2007) which is an important reproductive strategy and a shift toward a more efficient mechanism favoring germination and seedling establishment, contributing to population maintenance and short-distance dispersal (Cotá-Sánchez et al. 2007).

After ripening the E. phyllanthus fruit presents evident area of dehiscence, which is tiny portion of the fruit wall. From this suture, 
seeds and seedlings are visible, which facilitate the emergence and subsequent seedling growth inside and outside the fruit (Cota-Sánchez $\&$ Abreu 2007). The presence of this area of the dehiscence fruit facilitates the germination of seeds inside it because allow the gas exchange between internal and external of fruit wall and further the light passing through tiny portion of the fruit wall.

Based on the results presented in this paper, it is possible to conclude that $E$. phyllanthus seeds are highly sensitive to light and their germination was promoted by very low fluencies of light through the very low fluence response of phytochrome action, mediated by phyA, and through the low fluence response, mediated by phyB. At high temperatures a non phytochrome related process controls the seed germination. The interaction between light and temperature changes the light sensitivity in E. phyllanthus seeds under extreme temperatures.

\section{References}

AMARAL-BAROLI, A. \& TAKAKI, M. 2001. Phytochrome controls achene germination in Bidens pilosa $\mathrm{L}$. (Asteraceae) by very low fluence response. Braz. Arch. Biol. Technol. 44(2):121-124.

BASKIN, J.M. \& BASKIN, C.C. 1979. Promotion of germination of Stellaria media seeds by light from a green safe lamp. The New Phytol. 82(2):381-383.

BAUER, D. \& WAECHTER, J.L. 2006. Sinopse taxonômica de Cactaceae epifíticas no Rio Grande do Sul, Brasil. Acta Bot. Brasil. 20(1):225239.

BEWLEY, J.D. \& BLACK, M. 1994. Seed physiology of development and germination. 2 ed. Plenum Press, New York.

BOTTO, J.F., SÁNCHEZ, R.A., WHITELAM, G.C. \& CASAL, J.J. 1996. Phytochrome A mediates the promotion of seed germination by very low fluences of light and canopy shade-light in Arabidopsis. Plant Physiol. 110(2):439-444.

CONDE, L.F. 1975. Vivipary in Epiphyllum. Cactus Succul. J. 49(1):38-39.

COTA-SÁNCHEZ, J.H., REYES-OLIVAS, A. \& SÁNCHEZ-SOTO, B. 2007. Vivipary in coastal cacti: A potential reproductive strategy in halophytic environments. Am. J. Bot. 94(9):1577-1581.

COTA-SÁNCHEZ, J.H. \& ABREU, D.D. 2007. Vivipary and offspring survival in the epiphytic cactus Epiphyllum phyllanthus (Cactaceae). J. Exp. Bot. 58(14):3865-3873.

FENNER, M. \& THOMPSON, K. 2005. The Ecology of Seeds. Cambridge University Press, Cambridge.

FLORES, J., JURADO, E. \& ARREDONDO, A. 2006. Effect of light on germination of seeds of Cactaceae from the Chihuahuan Desert, Mexico. Seed Scie. Res. 16(2):149-155.

FLORES, J. \& BRIONES, O. 2001. Plant life-form and germination in a Mexican inter-tropical desert: effects of soil water potential and temperature. J. Arid Environ. 47(4):485-497.

FRANCO, A.C. 2002. Ecophysiology of woody plants. In The Cerrados of Brazil: ecology and natural history of a neotropical savanna (P.S. Oliveira \& R.J. Marquis, orgs). 1 ed. Columbia University Press, New York, p. 178-197.

KIMNACH, M. 1964. Epiphyllum phyllanthus. Cactus Succul. J. 36(4):105-115

KRONENBERG, G.H.M. \& KENDRICK, R.E. 1986. The physiology of action. In Photomorphogenesis in plants (R.E. Kendrick \& G.H.M. Kronenberg, eds). 1 ed. The Martius Nijhoff Publishers, The Netherlands, p. 99-114.

LABOURIAU, L.G. \& OSBORN, J.H. 1984. Temperature dependence of the germination of tomato seeds. J. Therm. Biol. 9(4):285-294.
MONDRAGON, D. \& CALVO-IRABIEN, L. 2006. Seed dispersal and germination of the epiphyte Tillandsia brachycaulos (Bromeliaceae) in a tropical dry Forest, Mexico. Southwest. Nat. 51(4):462-470.

NOLASCO, H., VEJA-VILASANTE, H.L., ROMERO-SCHMID, H.L. \& DIAZ-RONDERO, A. 1996. The effects of salinity, acidity, light and temperature on the germination of seeds of cardón (Pachycereus pringlei (S. Wats.) Britton \& Rose, Cactaceae). J. Arid Environ. 331:87-94.

PIMIENTA-BARRIOS, E., PIMIENTA-BARRIOS, E. \& NOBEL, P.S. 2004. Ecophysiology of the pitayo de Queretaro (Stenocereus queretaroensis). J. Arid Environ. 59(1):1-17.

RAMÍREZ-PADILLA, C.A. \& VALVERDE, L. 2005. Germination responses of three congeneric cactus species (Neobuxbaumia) with differing degrees of rarity. J. Arid Environ. 61(2):333-343.

ROJAS-ARÉCHIGA, M., CASAS, A. \& VÁZQUEZ-YANES, C. 2001. Seed germination of wild and cultivated Stenocereus stellatus (Cactaceae) from the Tehuacán-Cuicatlán Valley, Central México. J. Arid Environ. 49(2):279-287.

ROJAS-ARÉCHIGA, M. \& VÁZQUEZ-YANES, C. 2000. Cactus seed germination: a review. J. Arid Environ. 44(1):85-104.

ROJAS-ARÉCHIGA, M., VÁZQUEZ-YANES, C. \& OROZCO-SEGOVIA, A. 1998. Seed response to temperature of Mexican cacti species from two life forms: an ecophysiological interpretation. Plant Ecol. 135(2):207-214.

ROJAS-ARÉCHIGA, M., OROZCO-SEGOVIA, A. \& VÁZQUEZ-YANES, C. 1997. Effect of light on germination of seven species of cacti from the Zapotitlán Valley in Puebla, México. J. Arid Environ. 36(4):571-578.

SIMÃO, E., SOCOLOWSKI, F. \& TAKAKI, M. 2007. The epiphytic Cactaceae Hylocereus setaceus (Salm-Dick ex DC.) Ralf Bauer seed germination is controlled by light and temperature. Brazil. Arch. Biol. Technol. 50(4):655-662.

SMITH, H. 1975. Phytochrome and Photomorphogenesis: an introduction to the photocontrol of plant development. McGraw-Hill, London.

SOKAL, R.R. \& ROHLF, F.J. 1981. Biometry. W.H. Freeman, New York.

SUGAHARA, V.Y. \& TAKAKI, M. 2004. Effect of light and temperature on seed germination in guava (Psidium guajava L. - Myrtaceae). Seed Scie. Technol. 32(3):759-764.

TAKAKI, M. 2001. New proposal of classification of seeds based on forms of phytochrome instead of photoblastsm. Rev. Bras. Fisiol. Veg. 13(1):103-107.

TAKAKI, M., KENDRICK, R.E. \& DIETRICH, S.M.C. 1981. Interaction of light and temperature on the germination of Rumex obtusifolius L. Planta 152(3):209-214

TAKAKI, M., HEERINGA, G.H., CONE, J.W. \& KENDRICK, R.E. 1985. Analysis of the effect of light and temperature on the fluence response curves for germination of Rumex obtusifolius. Plant Physiol. 77(3):731-734.

TOMAZI, e.f. \& FIGUEIREDO, R.A. 2002. Efeito da ingestão por aves na germinação de sementes de Epiphyllum phyllanthus (Cactaceae) em Jundiaí - SP, Brasil. Argumento 3(7):11-15.

VÁLIO, I.F.M. \& SCARPA, F.M. 2001. Germination of seeds of tropical pioneer species under controlled and natural conditions. Rev. Bras. Bot. 24(1):79-84.

VALVERDE, T., QUIJAS, S., LÓPEZ-VILLAVICENCIO, M. \& CASTILLO, S. 2004. Population of Mammillaria magnimamma Haworth (Cactaceae) in a lava-field in Central Mexico. Plant Ecol. 170(2):167-184.

Received 11/09/09

Revised 23/01/10

Accepted 23/02/10 